\title{
Preliminary Analysis of Project-Based Teaching Material Development for Implementation in Hybrid Learning
}

\author{
Thamrin $^{1 *}$, Saidun Hutasuhut ${ }^{1}$, Joko Suharianto ${ }^{1}$, Reza Aditia ${ }^{2}$ \\ ${ }^{1}$ Faculty of Economics, Universitas Negeri Medan \\ ${ }^{2}$ Postgraduate School, Universitas Negeri Medan \\ *Corresponding author. Email: thamrin@unimed.ac.id
}

\begin{abstract}
This research is a preliminary analysis to determine the needs of students at the State University of Medan for project-based hybrid learning teaching materials in the research methodology course. Questionnaires were given to 30 respondents through an online questionnaire platform. After the data was collected and analysed, it was found that the respondents felt the need and wanted the research methodology course they received using project-based hybrid learning teaching materials.
\end{abstract}

Keywords: Hybrid learning, project-based learning

\section{INTRODUCTION}

Improving the quality of education in Indonesia is always carried out through improving education following the changes and developments of life that are currently happening in the 21 st century. An urgent quality improvement is carried out through improvements in the learning process of each subject offered to students. Therefore, lecturers are subject to always hopes that the learning activities carried out can achieve the goals set in an effective, efficient, exciting, and fun so that students can gain maximum competence. To realize these expectations, lecturers must develop learning designs following experience, knowledge, skills, and all available resources to support the optimal achievement of each learning activity.

Currently, in the Business Education Study Program, there are no Research Methodology teaching materials available in modules and textbooks, either in hard copy or project-based hybrids. The consequences of this condition impact students' unsatisfactory competence in writing proposals and conducting research for thesis writing. The consequence is that students are late in completing their lectures. Ideally, students can complete seven semesters of lectures.
However, none of the Unimed Business Education Study Program students can complete seven semesters of lectures. Based on the self-evaluation of the Business Education Study Program, on average, students complete their studies for eight semesters and three months.

Based on in-depth interviews with ten students who were researchers as thesis supervisors and examiners, information was obtained that one of the causes of this condition was that the teaching materials used in lectures had not been standardized and unattractive because they were still conventional and had not utilized information technology. Students also said that they wanted IT-based module teaching materials in the form of hybrid learning. Besides that, the learning model applied is not project-based, especially during the 2019 covid pandemic. Ideally, students should continue to practice through projects to write research proposals as an embryo for thesis writing.

This phenomenon cannot be allowed to continue because it is feared that students as prospective teachers do not have the competence to complete a quality thesis and are not competent in making scientific works as part of the duties of professional teachers when they become teachers so that the profile 
Table 1. Summary of respondent answer

\begin{tabular}{|c|c|}
\hline Question & "Yes" Answer (Percentage) \\
\hline $\begin{array}{l}\text { he implementation of Research Methodology learning so far } \\
\text { been exemplary according to your expectations so that you can } \\
\text { make a thesis proposal? }\end{array}$ & 92.1 \\
\hline $\begin{array}{l}\text { Is the Research Methodology course that you have been able to } \\
\text { take been considered easy and exciting? }\end{array}$ & 89.5 \\
\hline $\begin{array}{l}\text { Have you been aware of Hybrid learning and project-based } \\
\text { learning teaching materials? }\end{array}$ & 63.2 \\
\hline $\begin{array}{l}\text { Has the research methodology been implemented using hybrid } \\
\text { learning teaching materials with project-based learning? }\end{array}$ & 57.9 \\
\hline $\begin{array}{l}\text { Are you satisfied and have maximum competence in research } \\
\text { methodology course? }\end{array}$ & 78.9 \\
\hline $\begin{array}{l}\text { Do you feel that you need Hybrid learning teaching materials } \\
\text { with project-based learning in the Research Methodology course } \\
\text { to train your skills in making proposals in thesis preparation? }\end{array}$ & 89.5 \\
\hline $\begin{array}{l}\text { Do you feel that the research methodology courses you have } \\
\text { been studying so far (without hybrid learning) are less } \\
\text { interesting? }\end{array}$ & 57.9 \\
\hline $\begin{array}{l}\text { Do you agree that project-based hybrid learning can increase } \\
\text { your interest in education and your skills in preparing thesis } \\
\text { proposals? }\end{array}$ & 92.1 \\
\hline $\begin{array}{l}\text { Do you think that hybrid learning teaching materials with } \\
\text { project-based learning are indispensable in training the skills of } \\
\text { preparing proposals and improving the quality of thesis } \\
\text { proposals? }\end{array}$ & 97.4 \\
\hline $\begin{array}{l}\text { Do you think that hybrid learning teaching materials with } \\
\text { project-based learning are indispensable in training the skills of } \\
\text { preparing proposals and improving the quality of thesis } \\
\text { proposals? }\end{array}$ & 94.7 \\
\hline $\begin{array}{l}\text { Do you agree that research methodology lectures use hybrid } \\
\text { learning and project-based learning teaching materials? }\end{array}$ & 100 \\
\hline
\end{tabular}

of alumni of the Business Education Study Program to become professional teachers in high school cannot be realized. Efforts that can be made to overcome the problems above are by developing teaching materials for the Research Methodology course based on hybrid learning with a project-based learning model. This is in line with [3] research, which explains that hybrid learning if designed effectively, will attract student involvement in learning. The application of projectbased hybrids has a significant influence on the achievement of learning outcomes and creative thinking skills. The results of this study indicate that project-based hybrid is alternative learning following the demands of the twenty-first century. There is no difference between learning that uses tools with a project-based learning model and conventional learning tools to improve skills. This research gap encourages researchers to conduct this research.

\subsection{Project-Based Hybrid Learning}

In the era of the 21 st century, today's students represent the first generation to grow up with new technologies. They are considered the digital natives of Generation Z. They spend their entire lives surrounded by and using computers, video games, digital music players, video cameras, cell phones, and all the other toys and tools of the digital age. Today, the average college graduate spends less than 5,000 hours reading in their daily lives but more than 10,000 hours playing video gems (not to mention 20,000 hours watching TV) [1]. It was further explained that computer games, email, the Internet, cell phones, and instant messages were integral to their lives. Under these circumstances, school system policymakers must undertake renovations to educate the new generation.

Teaching materials are a set of systematically arranged materials that allow students to learn and are adapted to the existing curriculum. Teaching materials 
are a set of materials that contain learning material or content to achieve learning objectives. A teaching material contains material or lesson content in the form of ideas, facts, concepts, principles, rules, or theories that cover subjects according to their disciplines as well as other information in learning.

"Hybrid" or "mixed" is commonly used to describe courses that combine face-to-face classroom instruction with online learning. Hybrid learningbased modules are learning that combines learning delivery strategies using face-to-face and online activities (discussion/chat forums). Through hybrid learning-based learning, students are expected to learn independently, sustainably, and develop throughout their lives so that learning will be more effective, more efficient, and more enjoyable [2]. Furthermore, [3] state that hybrid learning, which combines face-toface and online activities, is the fastest-growing course in higher education.

Learning through this hybrid module has advantages: (1) students have greater time flexibility, freedom, and convenience by working part-time online from home (2) tend to interact more with lecturers and fellow students because there are many opportunities to do so well in class and online. (3) have access to the latest unlimited resources available through the Web. (4) can participate more in class discussions because they can choose an online or faceto-face environment where they feel more comfortable. (5). usually receive more feedback, and more frequent feedback, from lecturers. (6). can gain valuable skills from using the Internet and computer technology. Furthermore, [4] explained that students could interact with lecturers and other students by using this hybrid learning. Furthermore, this interaction significantly affects learning outcomes.

\section{METHOD}

This research is survey research to determine respondents' perceptions of something [5], [6]. This study uses stratified random sampling [6] in selecting the sample because the information it wants to know is the perception of students who have taken research methodology courses. To collect data, researchers used online questionnaires because, currently, this method is the most effective and efficient in capturing respondents' answers through a questionnaire instrument [6]. Data analysis using descriptive statistical analysis.

\section{RESULTS AND DISCUSSION}

A total of 30 respondents who are also students answered the questionnaire questions caused by using an online questionnaire platform. In table 1, it can be seen that the learning process has been running as expected. This is reflected in the respondents' answers to question number 1 and number 2 . A total of $92.1 \%$ of respondents answered that the implementation of learning was considered good. In addition, as many as $89.5 \%$ of respondents felt that so far, the study of the research methodology courses they were taking was easy and exciting. When asked whether the students already knew about hybrid learning and project-based learning teaching materials, $63.2 \%$ answered that they already knew. However, regarding whether this type of learning has been implemented in their classrooms, only $57.9 \%$ of respondents answered yes. The fifth question is whether they are satisfied and have maximum competence in the research methodology course; $78.9 \%$ answered yes.

Regarding whether they need hybrid learning with project-based learning in the research methodology course, $89.5 \%$ answered yes. When asked whether they feel that the research methodology courses you have been studying so far (without hybrid learning) are less attractive? As many as $57.9 \%$ answered that learning without hybrid learning was less attractive. The next question is whether they agree that projectbased hybrid learning can increase your interest in education and your skills in preparing thesis proposals. A total of $92.1 \%$ of respondents answered yes. For the question, do you think that hybrid learning teaching materials with project-based learning are indispensable in preparing proposals and improving the quality of thesis proposals? As many as $97.4 \%$ of respondents answered yes. The 10th question is, Do you think that hybrid learning teaching materials with project-based learning are indispensable in preparing proposals and improving the quality of thesis proposals? As many as $94.7 \%$ of respondents answered that they felt that this type of learning could improve the ability and quality of their thesis proposals. The last question is do you agree that research methodology lectures use hybrid learning and project-based learning teaching materials. For this question, all respondents $(100 \%)$ answered that they agree if this type of learning is applied in research methodology courses.

Based on the needs assessment carried out, it can be concluded that project-based hybrid learning teaching materials need to be developed. However, when the researcher carried out this needs analysis, all students at Medan State University entered a holiday 
period. Thus, the next step to be carried out is to develop teaching materials and carry out evaluations of these teaching materials, both one-to-one evaluations, small groups, and large groups.

\section{ACKNOWLEDGMENTS}

The author would like to thank to Universitas Negeri Medan by providing funds to this study, and to all respondents who participated in this study.

\section{REFERENCES}

[1] V. K. Ceylan and A. Elitok Kesici, "Effect of blended learning to academic achievement," $J$. Hum. Sci., vol. 14, no. 1, 2017, p. 308, doi: 10.14687/jhs.v14i1.4141.

[2] P. M. J. Tuapattinaya, "Pengembangan Media Pembelajaran Biologi Berbasis Hybrid Learning Untuk Meningatkan Hasil Belajar Siswa Pada Smp Negeri 6 Ambon," BIOSEL (Biology Sci. Educ. J. Penelit. Sci. dan Pendidik., vol. 6, no. 2, 2017, pp. 186-192.

[3] J. Shea, M. E. Joaquin, and M. Gorzycki, "Hybrid course design: Promoting student engagement and success," J. Public Aff. Educ., vol. 21, no. 4, 2015, pp. 539-556.

[4] P. Shea and T. Bidjerano, "Understanding distinctions in learning in hybrid, and online environments: An empirical investigation of the community of inquiry framework," Interact. Learn. Environ., vol. 21, no. 4, 2013, pp. 355370.

[5] J. W. Creswell, Educational reserach: planning, conducting and evaluating, 4th ed. Boston: Person, 2012.

[6] U. Sekaran and R. Bougie, Research Methods For Business: A Skill Building Approach. John Wiley \& Sons, 2016. 